Volume 7 Issue 1, March 2020

Nationally Accredited Journal,

Decree No. B/4130/E5/E5.2.1/2019

\title{
Islamic Justice Perspective on Notary the Perpetrators Criminal Action
}

\begin{abstract}
Ira Alia Maerani ${ }^{1}$
Abstract. This study aims to find out to know the form of violations and witnesses to the notary position based on Law No. 2 of 2014 concerning the Position of Notary and the perspective of Islamic justice in viewing a notary who is indicated to have committed a crime in connection with an authentic deed he made.

This research uses normative law research or dogmatic law research using the doctrinal method. Normative legal research includes research on legal principles, research on legal systematics, research on vertical and horizontal synchronization stages, comparison of law and legal history.

This research concludes that the notary public is a public official who makes an authentic deed and has the authority as regulated in Article 15,16, 17 of Law No. 2 of 2014 concerning the Position of Notary Public. The notary is obliged to act on trust; honest; independent; objective and safeguard the interests of parties involved in legal actions. Notaries in carrying out their duties and positions if convicted of violations, may be subject to sanctions or sanctions in the form of civil, administrative, and notary code of ethics in accordance with Law of the Republic of Indonesia Number 2 of 2014 concerning Notary Positions. Even so, the Notary Position Law does not regulate criminal sanctions against Notaries. Whereas in practice there is an opportunity for a legal action or violation by a notary related to an authentic deed he made that can be qualified as a criminal offense. A notary who is indicated to have committed a crime in carrying out his authority as a Public Official, of course, must be a concern of the government and law enforcement because the law must be upheld against anyone who commits indiscriminate violations. This rule is a manifestation of the principle of "equality before the law" (equality before the law) which is a fundamental element in the concept of the rule of law. Honesty values; keep the mandate; fair; and this objective is synergistic with the values of justice in an Islamic perspective that promotes justice and problems. Described in the Qur'an An-Nisa verses 58 and 135 and QS. Al Ma'idah verse 8. Islamic law also regulates justice in recording a deed, for example just in recording accounts receivable debts (Q.S. Al Baqoroh: 282)

Keywords: Islamic Perspective; Justice; Notary Public; Perpetrators; Criminal Act
\end{abstract}

\section{Introduction}

Interaction between humans in carrying out their social roles will go hand in hand with legal aspects because of their transactional nature. Considering the fact that it is transactional, it has consequences for the certainty of the transaction. This certainty has implications for the need for evidence in the form of authentic deeds.

The position of a notary public is a position because this position is appointed and dismissed by the government. The notary carries out the duties of the state and the deed he made, namely minuta (original deed), is a state document. In Indonesia, a notary is called a Public Official because it is appointed and dismissed by the public authority (the government) and given the authority and obligation to serve the public in certain matters, and therefore he participates in carrying out government authority ${ }^{2}$.

\footnotetext{
${ }^{1}$ Lecturer at the Faculty of Law, UNISSULA, Semarang email: ira.alia@unissula.ac.id

2 Soesanto, R. 1982. Tugas, Kewajiban dan Hak-hak Notaris, Wakil Notaris, Jakarta: Pradnya Paramita, page 75.
} 
The notary public officer is given the authority by the state to declare legal relations between the parties in a deed which directly records the agreement clauses of the promised parties.

In carrying out his position the notary must be able to behave professionally based on a noble personality by always carrying out his duties according to the applicable laws and regulations while at the same time upholding the code of ethics of the notary profession as a sign that must be obeyed. Notaries need to pay attention to what is referred to as professional behavior that has the following elements: (1) have strong moral integrity; (2) must be honest with both the client and yourself (intellectual honesty); (3) aware of the limits of their authority; and (4) not solely based on money considerations. $^{3}$

Article 16 letter a of Law Number 2 of 2014 concerning Notary Position (UUJN) stipulates that notaries are obliged to act honestly, thoroughly, independently, impartially and safeguard the interests of the parties involved in legal actions. In addition, the notary public official must be sensitive, responsive, have the sharpness of thinking and be able to provide a proper analysis of any legal phenomena and social phenomena that arise so that it will foster an attitude of courage in taking appropriate action. The courage referred to here is the courage to do the right legal actions in accordance with the applicable laws and regulations through the deed he made and refuses explicitly making the deed that is contrary to law, morals and ethics. ${ }^{4}$

Based on the above explanation, it can be said that the criminal liability of a notary in his position as a Public Official in the Indonesian justice system has not been specifically formulated. Therefore, in this study the writer makes a formulation of the problem, namely: how are the violations and sanctions regarding the notary position based on Law No. 2 of 2014?; What is the perspective of Islamic justice in looking at a notary who is indicated to have committed a crime in connection with the authentic deed he made?

\section{Research methods}

This research uses legal research that is normative legal research or dogmatic law research using doctrinal-normological methods that depart from the rules as teachings that cope with behavior. Normative legal research includes research on legal principles, research on legal systematics, research on vertical and horizontal synchronization stages, comparison of law and legal history. ${ }^{5}$

\section{Results And Discussion}

\subsection{Violations and Sanctions for the Position of Notary Public Based on Law No. 2 of 2014}

Notary is a public official who is authorized to make an authentic deed and has other authority as referred to in this Law or based on other laws (Article 1 of Law No. 2 of

\footnotetext{
${ }^{3}$ Liliana Tedjasaputro, 1995, Etika Profesi Notaris dalam Penegakan Hukum Pidana, Yogyakarta: Bigraf Publishing, page 86.

${ }^{4}$ Wawan Setiawan, "Sikap Profesionalisme Notaris dalam Pembuatan Akta Otentik", on Media Notariat, Edisi Mei-Juni 2004, page 25.

5 Soerjono Soekanto, 1985, Penelitian Hukum Normatif, Suatu Tinjauan Singkat, PT Raja Grafindo Persada, Jakarta, page 14.
} 
Volume 7 Issue 1, March 2020

Nationally Accredited Journal,

Decree No. B/4130/E5/E5.2.1/2019

2014 concerning the Position of Notary). In carrying out their duties, the authority of a notary is regulated in articles 15, 16 and 17 of Law No. 2 of 2014.

Article 15:

(1) The notary has the authority to make an authentic deed concerning all deeds, agreements and stipulations required by statutory regulations and / or desired by the parties concerned to be stated in an authentic deed, guaranteeing the certainty of the date of making the deed, keeping the deed, giving copies, copies and quotations of the Deed, all of that as long as the drafting of the Deed is not also assigned or excluded to other officials or other people determined by law.

(2) In addition to the authority referred to in paragraph (1), the Notary also has the authority:

a. ratify the signature and determine the certainty of the date of the letter under the hand by registering in a special book;

b. book a letter under the hand by registering in a special book;

c. make a copy of the original letter under the form of a copy containing the description as written and described in the letter concerned;

d. approve photocopying with the original letter;

e. provide legal counseling in connection with the making of the Deed;

f. make Deed relating to land; or

g. make the Deed of minutes of auction.

(3) In addition to the authorities as referred to in paragraph (1) and paragraph (2), the Notary Public shall have other authorities as stipulated in the legislation.

In addition to having the authority as stipulated in Article 15 above, the notary in carrying out his position, is obliged to do the following things as regulated in article 16 of the same Law.

Article 16:

(1) In the exercise of his office, the Notary shall:

a. acting trustworthy, honest, fair, independent, non-partisan, and maintaining the interests of the parties involved in legal action;

b. make the Act in the form of a Minute Act and keep it as part of the Notary Protocol;

c. affixing letters and documents and fingerprints to the Minute Act;

d. issue a Gross Act, Copy of the Act, or Collection of the Act based on the Minutes of the Act;

e. provide services in accordance with the provisions of this Act, unless there is a reason to reject them;

f. to conceal everything about the Act he made and all the evidence

g. obtained for the making of the Act in accordance with the oath / appointment of the department, except the law

h. determine another;

i. bind the Act he made within 1 (one) month of the book containing no more

j. of the 50 (fifty) Acts, and if the number of Acts cannot be contained in one book, the Act may be bound into more than one book, and shall record the Minute Act, month,

k. and the year it was made on the cover of each book;

I. making a list of the Act to protest against unpaid or receipt of valuable letters;

m. make a list of the Acts in respect of the will in the order in which the Act is made each month; 
n. submit a list of Acts as referred to in letter i or a list of wills in respect of a will to the will of the ministry which holds legal affairs within 5 (five) days of the first week of each month;

o. records in the repertory the date of mailing list at the end of each month;

p. has a stamp or stamp containing the national flag of the Republic of Indonesia and on

q. the space around which it contains the name, title, and place of residence;

$r$. read the Act in front of the audience by being attended by at least 2 (two) witnesses, or 4 (four) special witnesses for the making of the will under the hand, and signed at the same time by the witnesses, witnesses, and notaries; and

s. accepted a Notary candidate internship.

(2) The obligation to keep the Minutes of the Act as referred to in paragraph (1) letter b does not apply, in the case of the Notary issuing the Act in originally.

(3) The Act of origin as referred to in paragraph (2) includes:

a. Rental, interest, and retirement payments;

b. Cash payment offer act;

c. Act of protest against failure to pay or receipt of valuable letter;

d. Act of power;

e. Ownership deed; and

f. The other act is in accordance with the provisions of the law.

(4) The Act in originally as referred to in paragraph (2) may be made up of 1 (one) duplicate, signed at the same time, form, and content, provided that in each Act the words "APPLY TO ONE AND ONE ACT" FOR EVERYONE".

(5) The Act in originali containing the unnamed power of the assignee may only be made in 1 (one) duplicate.

(6) The shape and size of the stamp or stamp as referred to in paragraph (1) shall be prescribed by the Ministerial Regulations

(7) The reading of the Act as referred to in paragraph (1) of the letter is not obligatory, if the arbitrator requires the Act not to be read because the debtor has read himself, knows, and understands it, provided that it is stated in the closing of the Act and on each page Minutes of the Act are rated by witnesses, witnesses, and notaries.

(8) The provisions as referred to in paragraph (7) are exempt from reading the head of the Act, comparisons, brief explanations of the Act, and closing of the Act.

(9) If any of the conditions referred to in paragraph (1) of letter $m$ and paragraph (7) are not met, the Act concerned shall have the power of proof as an act under the hand.

(10)The provisions as referred to in paragraph (9) do not apply to the making of a Will.

(11)Notaries who violate the provisions of paragraph (1) letter a to letter I may be subject to sanctions in the following form:

a. written warning;

b. temporary cessation;

c. respectful dismissal; or

d. disrespectful dismissal.

(12)In addition to the sanctions as referred to in paragraph (11), a violation of the provisions of Article 16 paragraph (1) letter $\mathrm{j}$ may be a reason for the party suffering loss to demand compensation, damages, and interest to the Notary. 
Volume 7 Issue 1, March 2020

Nationally Accredited Journal,

Decree No. B/4130/E5/E5.2.1/2019

(13) Notaries who violate the provisions of paragraph (1) $n$ may be subject to sanctions in writing.

Between Article 16 and Article 17 is inserted 1 (one) Article, Article $16 \mathrm{~A}$, which reads as follows:

Article $16 \mathrm{~A}$

(1) The Notary Candidate applying for an internship is required to carry out the provisions of Article 16 paragraph (1) letter a.

In addition to the obligations referred to in paragraph (1), the Notary candidate is also obliged to keep everything in respect of the Act made by him and all the evidence obtained for the making of the Act.

The provisions of Article 17 are amended to read as follows:

Article 17

(1) Notaries are prohibited:

a. running a department outside his department;

b. leave his office for more than 7 (seven) consecutive business days without a valid reason;

c. as a civil servant;

d. assumes office as a state official;

e. holds a position as an advocate;

f. to hold office as a leader or officer of a state-owned enterprise, a state-owned enterprise or a private enterprise;

g. assumed office as the Land Law Office and / or Class II Auction Office outside a Notary position;

h. to be a Substitute Notary; or

i. doing other work that is contrary to religious norms, morals, or morals that may affect the honor and dignity of the Notary department.

(2) Notaries who violate the provisions of paragraph (1) may be subject to sanctions in the following form:

a. written warning;

b. temporary cessation;

c. respectful dismissal; or

d. disrespectful dismissal.

If he complies with some of the provisions of Law No. 2 of 2014, then the Notary will be subject to sanctions if he violates his profession. When it comes to sanctions imposed on a notary who violates it, it appears that the Notary may be subject to sanctions in the form of civil, administrative, and code of conduct notaries. This is further emphasized in article 9 as follows:

(1) The notary is temporarily suspended from office because:

a. in the process of bankruptcy or deferral of debt repayment obligations;

b. be under the influence;

c. committing a despicable act;

d. violate the obligation and prohibition of office and Notary's code of conduct; or

e. is currently under arrest.

Although the notary may be sanctioned, the Notary Department's law does not regulate criminal sanctions. Whereas in the notary's practice of practice the bias is not a legal act or a violation of the Notary's act in respect of his authentic act.

According to Habib Adjie, although the Notary Department's Law does not mention the enforcement of the sanctions, but if a legal action against the notary's violation 
contains elements of forgery / negligence in the making of an authentic affidavit letter / deed, after being subjected to administrative notices / codes of ethics of the notary department and civil sanctions, can then be withdrawn and qualified as a crime committed by the Notary explaining the existence of evidence of intentional involvement in the crime of forgery of the authentic act. ${ }^{6}$

\subsection{Islamic Justice Perspective on Criminal Notaries}

In Islam, devine justice is found in the revelation of God and the wisdom that the Prophet Muhammad conveyed to his people. The first is in the Qur'anic scriptures and the second is in the Hadith of Prophet Muhammad. ${ }^{7}$

In Islam, ALLAH is the holder of sovereignty; He is the ruler and the lawgiver. The revelation of God and the wisdom of the Holy Prophet is the primary source of building a growing order of society. The principles of building public order, meeting the needs and expectations of a growing society. The principles and teachings of justice drawn from revelation and divine wisdom are considered perfect and inviolable, created for all time and have the potential to apply to all mankind. In principle, the law that God has established is an ideal and perfect system. But public order, consisting of laws, state regulations, rules (furu) and opinions of experts on issues raised through human reasoning, when necessary can be adapted and refined to meet the conditions, changing conditions and the needs of a growing society. ${ }^{8}$

The theory of justice or the theory of evil in the Islamic perspective is constantly being studied by philosophers of Islamic Law (ushul fiqih), especially when discussing the question of maqashid tasyri' or maqashid syariah. The theory of justice from an Islamic perspective is objective, universal (universal and universal) and universal.

Prosperity and justice are at the core of Islamic Law. This is evidenced by the many verses of the Qur'an that deal with justice and goodwill among others: QS. An Nisa 'Verses 58 and 135, and QS. Al Maidah: 8. Further the verses are described below:

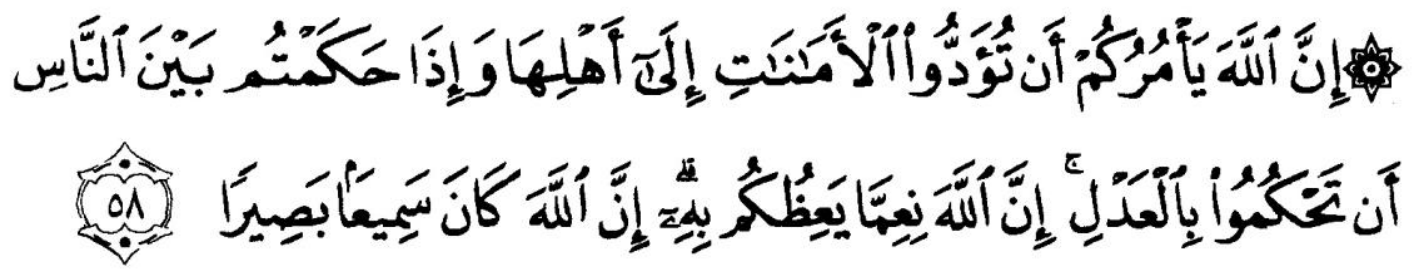

It means: "Indeed, Allah has commanded you to give the mandate to those who are entitled to it, and (to ask you) to establish the law among men, that you may judge justly. Indeed, GOD has given you the best lessons. Verily, Allah is All-Hearing, AllSeeing. " (QS. An Nisa ': 58)

${ }^{6}$ Habib Adjie, 2008, Hukum Notaris di Indonesia: Tafsir Tematik Terhadap UndangUndang Nomor 30 Tahun 2004 tentang Jabatan Notaris,Bandung:Refika Aditama,page 25

7 Topo Santoso, 2016, Asas-Asas Hukum Pidana Islam, Cetakan Pertama, Rajawali Pers, Jakarta, page 84-87 cited from Majid Khadduri, 1984, The Islamic Concept of Justice, The Johns Hopkins University Press, Baltimore and London, page 2.

${ }^{8}$ Ibid. 
Volume 7 Issue 1, March 2020

Nationally Accredited Journal,

Decree No. B/4130/E5/E5.2.1/2019

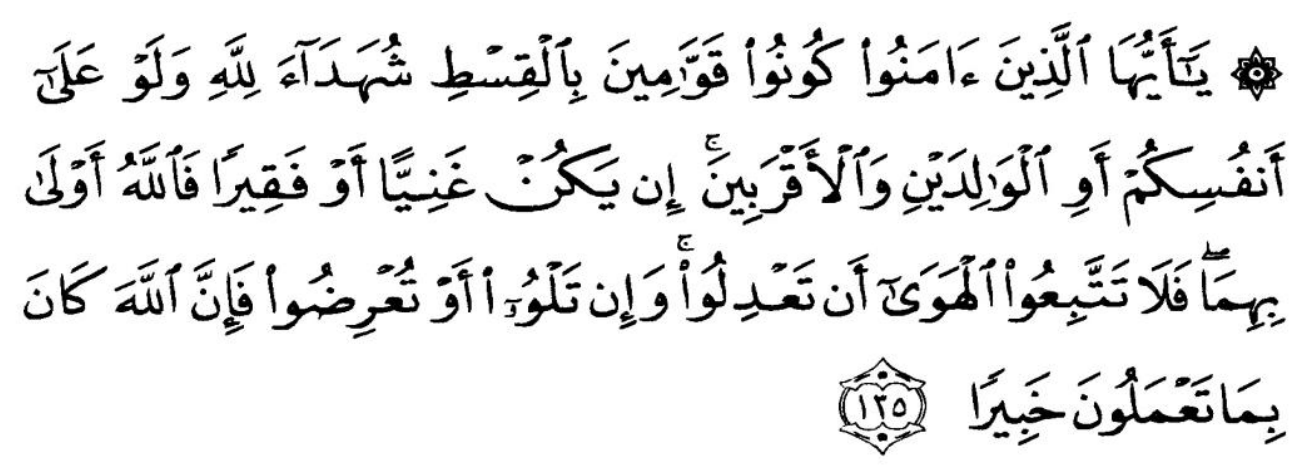

It means: "O you who believe, be a person who truly upholds justice, be a witness because GOD even though yourself or your father and your relatives. If he is rich or poor, God knows his benefit better. Then do not follow the passions because you want to deviate from the truth. And if you distort (words) or are reluctant to be a witness, then surely ALLAH is All-Knowing everything you do. "(Surat an-Nisa ': 135)

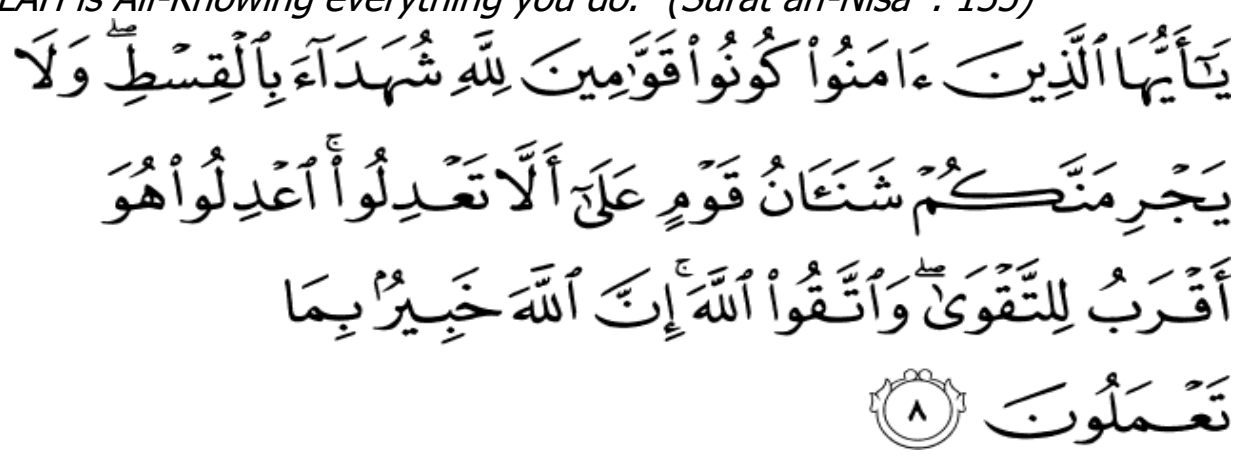

It means: "O you who believe, you should be those who always uphold (the truth) because GOD, be a fair witness. And do not ever have your hatred towards a people, pushing you to be unjust. Be fair, because fair is closer to piety. And fear Allah, surely Allah is well aware of what you are doing. " (Surah Al Maidah: 8)

Justice is the key word in terms of law enforcement. Like a coin coin becomes an inseparable part. Relation to criminal law, of course, is an important thing that is applied to justice in the criminal justice system and implementation. The word "just" means to set the law correctly. So a fair person is walking straight and his attitude always uses the same size, not double. "Equality" is what the origin of the word "just" means, which makes the perpetrator "impartial" to one of the disputants, and basically also a fair person sides with the right "because both the right and the wrong must get his rights. Thus, he did something appropriate and not arbitrary. ${ }^{9}$

Professor of the Faculty of Law of the University of Diponegoro, Eko Soponyono, in his inaugural speech the Professor stated the Fair Concept in the Wisdom of the Qur'an in the information below: ${ }^{10}$

9 Ira Alia Maerani, 2018, Hukum Pidana dan Pidana Mati, Unissula Press, Semarang cited from Konsep Keadilan Dalam Al-Qur'an, http://el-fathne.blogspot.co.id/2010/05/konsepadil-dalam-al-quran.html

10 Eko Soponyono, 2017, Hikmah Al-Qur'an dalam Pembaharuan Hukum Pidana Demi Mewujudkan Keadilan Religius, Professor Inaugural Speech in the field of Legal Science at Faculty of Law Diponegoro University, Semarang, 9 September 2017, page 30-34 
Islam requires the Ummah to be fair in all matters. The Qur'an distributes the obligation of a just attitude in several matters such as:

Establish the Law

"Indeed, ALLAH told you to deliver the message to those who are entitled to receive it and (to order you) if you establish a law between humans so that you determine it fairly." (Qur'an, An-Nisa: 58)

The mandate in the above words can be understood from three things: First: the message of the servant with his Rabb, namely what God has promised him to be kept in the form of carrying out all his commands, avoiding all his prohibitions and using all his feelings and limbs for things that are beneficial and closer to Rabb. Second: the message of the servant with fellow human beings, for example returning the deposit to the owner, not deceiving, keeping secrets and so forth that must be done to the family, relatives, humans in general and the government. Third: the mandate of humans towards themselves, such as choosing the most appropriate and beneficial for him in matters of religion and the world.

Just in the words above means giving sanctions and penalties in accordance with what has been prescribed by GOD through His Prophet. Asy-Syahadah (testimony) here, is meant to state the truth to the judge, so that a law is decided based on that truth. Or, it is the judge who declares the truth by deciding or acknowledging it for those who do the truth. So basically it is fair without bias, both to the person being witnessed or the event witnessed, may not be biased, either because of relatives, wealth or rank, and must not leave justice, either because of relatives, property or rank, and may not leaving justice, whether due to poverty or poverty. Do not enmity and hatred towards a people pushes to be unfair to them, for example an accused who is of different religion with a witness, then they must also continue to testify with something they deserve if they really deserve it. That justice is an obligation that must be fulfilled regardless of anyone. Because justice is what is closer than taqwa to GOD and avoiding His wrath.

In Islam it also regulates justice in recording the deed, for example fair in recording accounts receivable

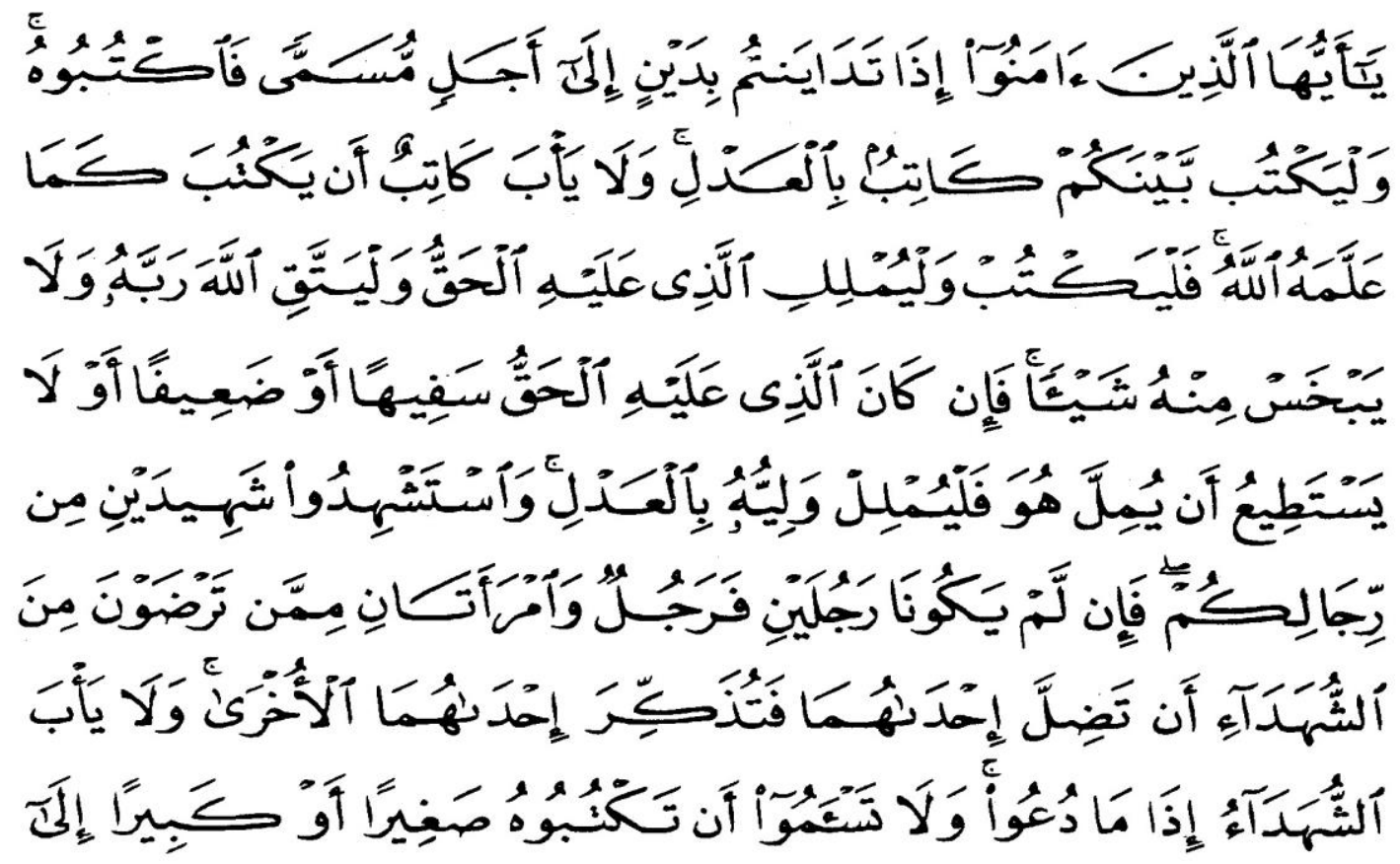


Volume 7 Issue 1, March 2020

Nationally Accredited Journal,

Decree No. B/4130/E5/E5.2.1/2019

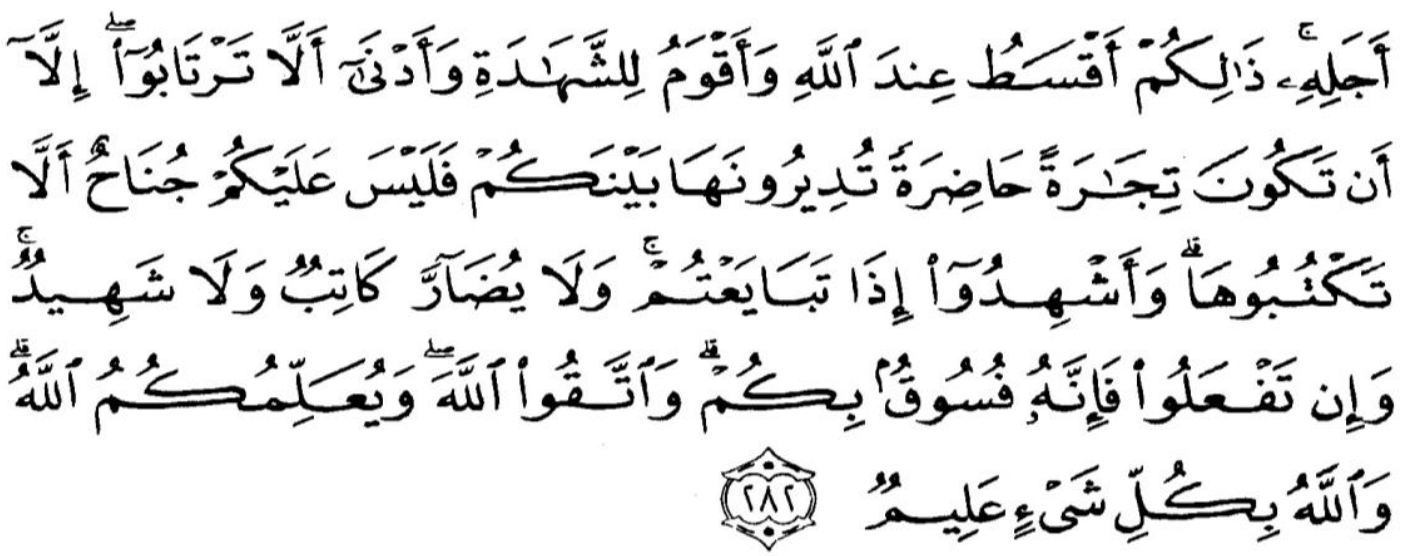

It means: "O you who believe, if you do not start in cash for a specified time, you should write it down. And let a writer among you write it correctly. And let the writer not be reluctant to write it as God taught it, they should write it, and let the person who owes it teach (what will be written it), and let him fear Allah, his Lord, and let him not reduce the slightest of his debt. If the person who is in debt is a person whose mind is weak or weak (his condition) or he himself is unable to lead, then his guardian should teach him honestly. And witness with two witnesses of the men (among you). If there are no two men, then (it is permissible) a man and two women from witnesses that you are pleased with, so that if one forgets one person reminds him. Do not be reluctant witnesses (provide information) when they are called; and do not be weary of writing that debt, whether small or large until the deadline to pay it. That is, it is fairer with Allah and strengthens testimony and is closer to not (raising) your doubts. (Write thy muamamamu), except if thy muamam is a cash trade that you run among you, then there is no sin for you, (if) you do not write it. And witness if you sell and buy; and don't let the writer and witness make it difficult for each other. If you do (that is), then surely it is a wickedness in yourself. And fear Allah; God teaches you; and Allah knows everything. " (Surat al-Baqarah: 282)

In this context, a notary who is indicated to have committed a crime in carrying out his profession, then a crime can still be committed based on the principle of equality before the law and based on the principle of justice.

\section{Conclusion}

Notaries in carrying out their duties and positions if convicted of violations, may be subject to sanctions or sanctions in the form of civil, administrative, and notary code of ethics in accordance with Law of the Republic of Indonesia Number 2 of 2014 concerning Notary Positions. Even so, the Notary Position Law does not regulate criminal sanctions against Notaries. Whereas in practice there is an opportunity for a legal action or violation by a notary related to an authentic deed he made that can be qualified as a criminal offense.

A notary who is indicated to have committed a crime in carrying out his authority as a Public Official, of course, must be a concern of the government and law enforcement because the law must be upheld against anyone who commits indiscriminate violations. This rule is a manifestation of the principle of "equality before the law" (equality before the law) which is a fundamental element in the concept of the rule of law. 
Based on the principle of equality before the law, every individual and community group has the same submission before the law, so there are no exceptions for government officials or certain people to the law governing citizens as a whole.

In the perspective of Islamic justice, anyone who commits legal actions or violations must continue to uphold justice. In this context, the violation is processed in accordance with the provisions of the legislation regulated in the Criminal Code.

\section{References}

[1] Al Qur'an and Translation, PT. Karya Toha Putra, Semarang.

[2] Eko Soponyono, 2017, Hikmah Al-Qur'an dalam Pembaharuan Hukum Pidana Demi Mewujudkan Keadilan Religius, Professor Inaugural Speech in the field of Legal Science at Faculty of Law Diponegoro University, Semarang, 9 September 2017

[3] Habib Adjie, 2008, Hukum Notaris di Indonesia: Tafsir Tematik Terhadap UndangUndang Nomor 30 Tahun 2004 tentang Jabatan Notaris,Bandung:Refika Aditama.

[4] Ira Alia Maerani, 2018, Hukum Pidana dan Pidana Mati, Unissula Press, Semarang

[5] Liliana Tedjasaputro, 1995, Etika Profesi Notaris dalam Penegakan Hukum Pidana, Yogyakarta: Bigraf Publishing.

[6] Soerjono Soekanto, 1985, Penelitian Hukum Normatif, Suatu Tinjauan Singkat, PT Raja Grafindo Persada, Jakarta,

[7] Soesanto, R. 1982. Tugas, Kewajiban dan Hak-hak Notaris, Wakil Notaris, Jakarta: Pradnya Paramita

[8] Topo Santoso, 2016, Asas-Asas Hukum Pidana Islam, Cetakan Pertama, Rajawali Pers, Jakarta

[9] Wawan Setiawan,"Sikap Profesionalisme Notaris dalam Pembuatan Akta Otentik",dalam Media Notariat, Edisi Mei-Juni 2004. 